\title{
Effect of lectin (ScLL) on fibroblasts stimulated with LPS - an in vitro study
}

\begin{abstract}
Manuella Verdinelli de Paula REIS(a) Camilla Christian Gomes MOURA ${ }^{(b)}$ Marcus Vinicius da SILVA(c) Maria Aparecida de SOUZA ${ }^{(\mathrm{d})}$ Priscilla Barbosa Ferreira SOARES ${ }^{(\mathrm{e})}$ Carlos José SOARES(a)
\end{abstract}

(a) Universidade Federal de Uberlândia - UFU, School of Dentistry, Biomechanics Research Group, Department of Operative Dentistry and Dental Materials, Uberlândia, MG, Brazil.

(b) Universidade Federal de Uberlândia - UFU, School of Dentistry, Biomechanics Research Group, Department of Endodontics, Uberlândia, MG, Brazil.

(c) Universidade Federal do Triângulo Mineiro - UFTM, Institute of Biomedical Sciences, Department of Immunology, Uberaba, MG, Brazil.

(d) Universidade Federal de Uberlândia - UFU, Institute of Biomedical Sciences, Department of Immunology, Uberlândia, MG, Brazil.

(e) Universidade Federal de Uberlândia - UFU, School of Dentistry, Biomechanics Research Group, Department of Periodontology and Implantology, Uberlândia, MG, Brazil.

Declaration of Interests: The authors certify that they have no commercial or associative interest that represents a conflict of interest in connection with the manuscript.

\section{Corresponding Author:}

Carlos José Soares

E-mail: carlosjsoares@ufu.br

DOI: 10.1590/1807-3107BOR-2016.vol30.0140

Submitted: Dec 8, 2015

Accepted for publication: Jul 28, 2016

Last revision: Nov 11, 2016
Abstract: The lectin (ScLL) extracted from the Synadenium carinatum plant has been evaluated as an immunomodulator in diseases such as asthma, neosporosis and leishmaniasis. However, it has not yet been evaluated in the oral cavity. This study evaluated the effect of ScLL on viability, proliferation and release of IL-10 in human gingival fibroblasts (HGF) stimulated with lipopolysaccharide (LPS). HGF were stimulated with LPS $1 \mu \mathrm{g} / \mathrm{ml}$ and treated with ScLL in concentrations of 10,5 and $2 \mu \mathrm{g} / \mathrm{ml}$ for 1 and $5 \mathrm{~h}$, and evaluated by flow cytometry for viability, apoptosis (initial/advanced) and necrosis. The supernatant was collected to detect release of IL-10 by ELISA. The proliferation was assessed with the BrdU assay. Positive control consisted of cells maintained in Dulbecco's Modified Eagles Medium (DMEM), and the negative control, of those kept in tap water. Data were analyzed by ANOVA and Dunnett's test $(\alpha=0.05)$. No significant difference was found for ScLL concentrations regarding viability or initial and advanced apoptosis $(p=0.455)$. All the groups, including the positive control, had a significantly lower necrosis parameter than negative control at $5 \mathrm{~h}(\mathrm{p}<0.001)$. No difference was found for proliferation among the experimental groups $(\mathrm{p}=0.832)$. ScLL at 5 and $2 \mu \mathrm{g} / \mathrm{ml}$ resulted in a lower release of IL-10 than positive and negative controls at $5 \mathrm{~h}(\mathrm{p}=0.047)$. The results indicated that ScLL concentrations tested were not cytotoxic, and had no effect on proliferation and release of IL-10 parameters. A thorough understanding of ScLL, regarding its immunomodulatory potential, may open the door to new perspectives for dentistry.

Keywords: Mannose-binding Lectin; Fibroblasts; Lipopolysaccharides; Cell Survival; Tooth Avulsion.

\section{Introduction}

Dental avulsion is considered a severe dental trauma resulting from the complete displacement of a tooth from its alveolar socket. The periodontal ligament (PDL), alveolar bone, gingival mucosa and dental pulp tissue are frequently affected., ${ }^{1,2}$ The damage may be irreversible, resulting in root resorption, ankylosis or tissue necrosis, which influence tooth replantation prognosis. ${ }^{1,2,3}$ Considering that immediate replantation is not always possible, it is important to preserve the PDL cells for successful replantation of the avulsed tooth. ${ }^{1,2}$ Studies have been performed to determine an effective method for preserving PDL cells using different 
storage media, such as Hank's Balanced Salt Solution (HBSS), milk and coconut water. ${ }^{2,4}$ However, the psychological factors involved at the time of the accident, and, especially, the lack of information about first aid regarding tooth avulsion, may result in delayed replantation, which often occurs after a longer extra-alveolar dry period. ${ }^{1,2}$ In these cases, the response of a tooth to an injury triggers a biochemical chain reaction; in this process, the fibroblasts are the first cells to respond to the early signs of tissue damage. ${ }^{5}$ PDL cells are responsible for maintaining the integrity of the root; irritation or injury to these cells may cause damage to the cementum and dentin. Consequently, clastic cells will be attracted to the areas of the exposed dentin surface, leading to root resorption. ${ }^{1,3,5}$ In addition, exposure of root dentin proteins, phosphophoryn and sialoprotein, may also cause an immunopathological reaction. ${ }^{6}$

Antiresorptive substances such as alendronate, ${ }^{7}$ gallium nitrate ${ }^{8}$ and Emdogain ${ }^{3,9}$ have been studied for root surface treatment associated with later replantation. However, these agents yielded unsatisfactory results in controlling or preventing root resorption. ${ }^{3,9}$ Considering that root resorption has an immune-inflammatory aspect, ${ }^{10}$ it would be interesting to evaluate substances capable of modulating the cascade of molecular events. Although the mechanism of traumatic resorption is complex and poorly understood, osteoprotegerin (OPG) and the receptor activator of nuclear factor-kappa $B$ ligand (RANKL) are known regulators of bone formation. ${ }^{10}$ The effects of RANKL are opposite from those of OPG; consequently, the disruption of OPG/RANKL pathways leads to low bone mass, which may contribute to root resorption. ${ }^{11}$ Moreover, OPG and RANKL are mediated by the Wnt signaling pathway that simultaneously downregulates RANKL and upregulates OPG in the presence of a positive stimulus. ${ }^{12}$ Thus, the latter contributes to bone formation and inhibits bone resorption. ${ }^{12}$ Considering that RANKL and OPG are regulated by modulators of the immune system (hormones and cytokines), ${ }^{10}$ treatment of the root surface using immunomodulatory active components of medicinal plants would be a new and interesting challenge.
Latex extracted from the Euphorbiaceae Synadenium carinatum plant yields D-galactose binding lectin (ScLL). ${ }^{13}$ Lectins are involved in several biological events, such as endocytosis, cell migration, cell regulation and immune defense processes. ${ }^{14}$ The anti-inflammatory effects of ScLL have been successfully demonstrated in models of chronic inflammation, ${ }^{13}$ leishmaniasis ${ }^{15}$ and neosporosis. ${ }^{16}$ Despite its anti-inflammatory activity, ${ }^{13,15,16}$ ScLL has not been evaluated in the oral cavity until the present time. The purpose of the present study was to investigate the effect of ScLL, stimulated with Porphyromonas gingivalis lipopolysaccharides (LPS), on the viability, proliferation and release of IL-10 in gingival fibroblasts. The first null hypothesis was that cells stimulated with LPS and treated with ScLL would not affect proliferation or cell viability. The second null hypothesis was that the levels of IL-10 would be the same for both treated and control groups.

\section{Methodology}

\section{Cell culture}

Immortalized human gingival fibroblasts (HGF) (Cell Bank of Rio de Janeiro, Rio de Janeiro, RJ, Brazil) were used in the present study. The cells were cultured in T-50 flasks containing Dulbecco's Modified Eagles Medium (DMEM) (Vitrocell Embriolife, Campinas, SP, Brazil), supplemented with $10 \%$ fetal bovine serum (FBS) (Vitrocell Embriolife), in a humidified incubator with $5 \% \mathrm{CO}_{2}$ and $95 \%$ air at $37^{\circ} \mathrm{C}$, until confluence. The HGF were trypsinized with trypsin-EDTA (Sigma-Aldrich, St. Louis, MO, USA), counted in a hemocytometer and seeded into 96-well plates (Coastar Corp., Cambridge, MA, USA) at $2 \times 10^{4}$ cells/well in DMEM with $10 \%$ FBS. After $24 \mathrm{~h}$, the cells were stimulated with $1 \mu \mathrm{g} / \mathrm{ml}$ of LPS from P. gingivalis (Invivogen, San Diego, CA, USA) in DMEM with 10\% FBS for $24 \mathrm{~h}$. Then, the medium containing LPS was removed and the cells were treated with 10, 5 and $2 \mu \mathrm{g} / \mathrm{ml}$ of ScLL (Federal University of Uberlandia Herbarium) in a fresh, serum-free medium for 1 and $5 \mathrm{~h}$. The positive control group contained the cells maintained in 10\% DMEM (not LPS-stimulated), representing their physiological behavior. The negative control group contained the cells kept in tap water (LPS-stimulated), mimicking the worst clinically 
occurring situation. The tests were performed with six samples per group. After the incubation period with ScLL, the culture medium supernatant was collected for IL-10 dosage by ELISA. The cells were prepared for analysis by flow cytometry.

\section{Flow Cytometry}

This assay was performed following ScLL treatment, using an Annexin V/Dead Cell Apoptosis Kit (Invitrogen, Carlsbad, CA, USA), according to the manufacturer's instructions. The HGF were trypsinized, rinsed with phosphate-buffered saline (PBS) and re-suspended using annexin buffer. The cells were incubated using $5 \mu$ of annexin $\mathrm{V}$ and $1 \mu \mathrm{l}$ of propidium iodide (PI; $100 \mu \mathrm{g} / \mathrm{ml}$ ) for 15 minutes. Flow cytometric analysis was performed using a FACSCalibur flow cytometer (BD Biosciences, San Jose, CA, USA). The data were obtained using CellQuest 5.1 software (BD Biosciences) and analyzed using FlowJo software (TreeStar Inc., Ashland, OR, USA). The results were converted into percentages, according to medium fluorescence intensity.

\section{Cell Proliferation Assay}

The proliferation rate of HGF cells was determined using a bromodeoxyuridine (BrdU) staining kit
(Invitrogen). Then $2 \times 10^{4}$ cells were seeded on coverslips in 48 -well plates for $24 \mathrm{~h}$. The HGF were stimulated with or without LPS and treated with ScLL for the same duration described previously. Next, the cells were incubated in a humidified incubator with $5 \% \mathrm{CO}_{2}$ and $95 \%$ air at $37^{\circ} \mathrm{C}$ for 3 days to evaluate the proliferation potential assay. After this period, the HGF were labelled with BrdU for $24 \mathrm{~h}$, fixed with methanol for 30 minutes at $4^{\circ} \mathrm{C}$, and stained according to the kit procedure for cultured cells. Three samples per condition were used in this test.

Three images of each coverslip were taken at $10 \mathrm{x}$ magnification for analysis. The images were taken using a digital camera (DXM-1200, Nikon, Tokyo, Japan) attached to an optical microscope (Nikon Eclipse E200). The number of positive proliferative nucleic cells were counted and expressed in percentages, for statistical analysis (Figure $1 \mathrm{~A}-\mathrm{J}$ ).

\section{Cytokine Assay}

The number of IL-10 cytokines released in the cell culture supernatants was evaluated using a sandwich ELISA kit (PeproTech, Rocky Hill, NJ, USA), according to the manufacturer's instructions. Absorbance was recorded using a microplate reader
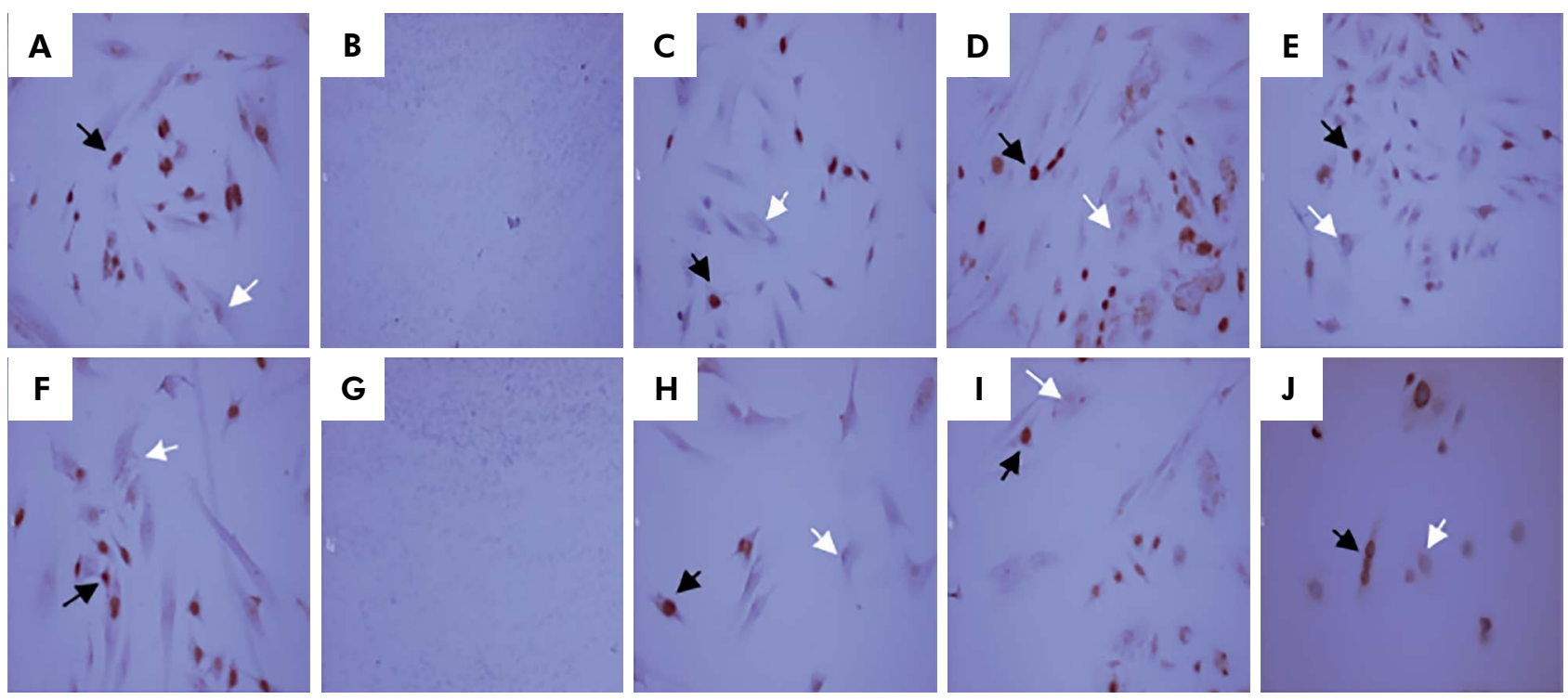

Figure 1. BrdU assay of HGF cells showed proliferative cells represented by labeled brown nucleus (black arrow) and no labeled nucleus (white arrow). Positive control group (DMEM) at $1 \mathrm{~h}(\mathrm{~A}) ;$ Negative control group (tap water) at $1 \mathrm{~h}(\mathrm{~B}) ; \mathrm{ScLL} 10 \mu \mathrm{g} / \mathrm{ml} \mathrm{at}$ $1 \mathrm{~h}(\mathrm{C}) ; \mathrm{ScLL} 5 \mu \mathrm{g} / \mathrm{ml}$ at $1 \mathrm{~h}(\mathrm{D}) ; \mathrm{ScLL} 2 \mu \mathrm{g} / \mathrm{ml}$ at $1 \mathrm{~h} \mathrm{(E);} \mathrm{DMEM} \mathrm{at} 5 \mathrm{~h}(\mathrm{~F}) ; \operatorname{Tap}$ water at $5 \mathrm{~h}(\mathrm{G}) ; \mathrm{ScLL} 10 \mu \mathrm{g} / \mathrm{ml}$ at $5 \mathrm{~h}(\mathrm{H}) ; \mathrm{ScLL} 5 \mu \mathrm{g} / \mathrm{ml}$ at $5 \mathrm{~h} \mathrm{(I);ScLL} 2 \mu \mathrm{g} / \mathrm{ml}$ at $5 \mathrm{~h}(\mathrm{~J})$. $10 \times$ magnification. Bars scale $10 \mu \mathrm{m}$. 
(Biochrom, Cambridge, UK) at $405 \mathrm{~nm}$ wavelength. The results obtained for absorbance were interpolated into a standard curve, using the Microplate Manager 4.0 software (Bio-rad, Hercules, CA, USA).

\section{Statistical Analysis}

Data of flow cytometry (cell viability, advanced apoptosis and necrotic cells), proliferation and IL-10 were analyzed for normality and homoscedasticity using Shapiro-Wilk's and Levene's tests. The one-way ANOVA and Tukey tests were used to compare data for cell viability, advanced apoptosis, necrotic cells, proliferation and IL-10 between the treated groups. Initial apoptosis was analyzed using the Kruskal-Wallis test $(p<0.05)$. Dunnett's test was used to compare the control groups (positive and negative) with the experimental groups. Statistical significance was set at $\alpha=0.05$. Statistical analysis was performed using Sigma Plot 12.0 software (Systat Software, San Jose, CA, USA).

\section{Results}

\section{Cell viability, apoptosis and necrosis}

Figure 2A shows cell viability and standard deviations. No significant differences were found among cell viability $(p=0.455)$, initial apoptosis and advanced apoptosis $(p=0.956)$ for the groups treated with different concentrations of ScLL (Figure 2A-C). The percentage of necrotic cells was statistically higher for the group treated with ScLL $2 \mu \mathrm{g} / \mathrm{ml}$ at $1 \mathrm{~h}$, compared with the other ScLL treated groups $(p=0.001)$. No significant differences were found among the groups (Figure 2D) at $5 \mathrm{~h}$. All the ScLL treated groups and the negative control group had lower percentages of viable cells at $1 \mathrm{~h}$ and $5 \mathrm{~h}$, compared with the positive control $(p=0.002)$.

Regarding the initial apoptosis, no significant difference was found between the ScLL treatments and the positive control at $1 \mathrm{~h}$. However, the values were significantly higher for the treated groups at $5 \mathrm{~h}$, compared with the positive control $(\mathrm{p}<0.001)$. All the ScLL treated groups had significantly higher values for advanced apoptosis than the positive control $(p<0.001)$ at $1 \mathrm{~h}$. No statistically significant difference was found between the positive control and the ScLL treated groups at $5 \mathrm{~h}$.
The percentage of necrotic cells was statistically higher for the treated group than the positive control at $1 \mathrm{~h}$. However, no significant differences were found among the groups at $5 \mathrm{~h}$. The negative control showed the lowest percentage of viable cells of all groups, regardless of the evaluation time $(p<0.001)$. The initial apoptosis presented similar values for the ScLL treated groups and the negative control at $5 \mathrm{~h}$. The advanced apoptosis values were significantly higher for the negative control group, compared with all other the groups ( $\mathrm{p}<0.001)$, at 1 and $5 \mathrm{~h}$. The level of necrosis for the positive control was lower than the negative control $(p<0.001)$ at $1 \mathrm{~h}$. All ScLL treated groups and the positive control group had significantly lower values than the negative control $(\mathrm{p}<0.001)$ at $5 \mathrm{~h}$.

\section{Cell proliferation}

Cell proliferation means and standard deviations are shown in Figure 3. Cell proliferation was similar for all experimental groups $(\mathrm{p}=0.832)$. The groups treated with ScLL $2 \mu \mathrm{g} / \mathrm{ml}$ and ScLL $5 \mu \mathrm{g} / \mathrm{ml}$ presented proliferation values similar to those of the positive control group, regardless of the time evaluated. The negative control group had lower values than those of the treated groups, for all tested concentrations except ScLL $10 \mu \mathrm{g} / \mathrm{ml}$ at $5 \mathrm{~h}(\mathrm{p}<0.001)$. Cell proliferation for the positive control group was significantly higher, compared with the negative control group, regardless of the time point analyzed $(p<0.001)$.

\section{Release of IL-10}

Figure 4 shows means and standard errors for the release of IL-10. Similar values were found for the positive control and the ScLL treated groups at $1 \mathrm{~h}$, except for ScLL $10 \mu \mathrm{g} / \mathrm{ml}$, which showed lower IL-10 ( $p=0.026)$ release. ScLL treated groups had values similar to those of the negative control group at $1 \mathrm{~h}$. Dunnett's test showed that treatment with ScLL 5 and $2 \mu \mathrm{g} / \mathrm{ml}$ resulted in lower releases of IL-10 than those of the positive and negative control groups at $5 \mathrm{~h}(\mathrm{p}<0.001)$.

\section{Discussion}

The effect of different ScLL concentrations on the viability, proliferation and release of IL10 using immortalized HGF cells was evaluated in the present study. The use of immortalized cell cultures in a 
A

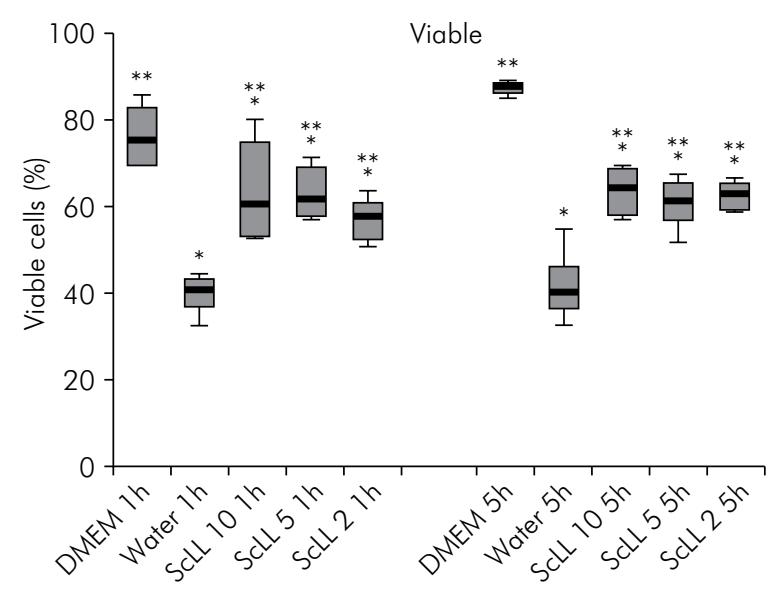

C

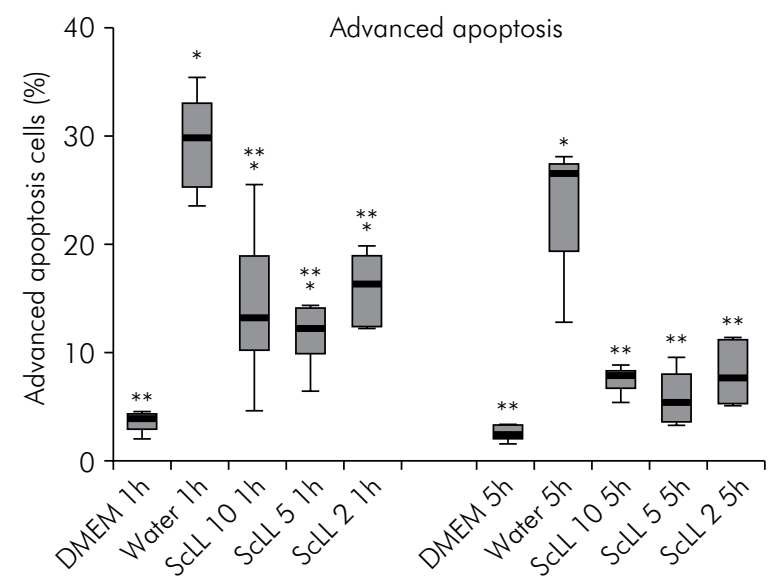

B

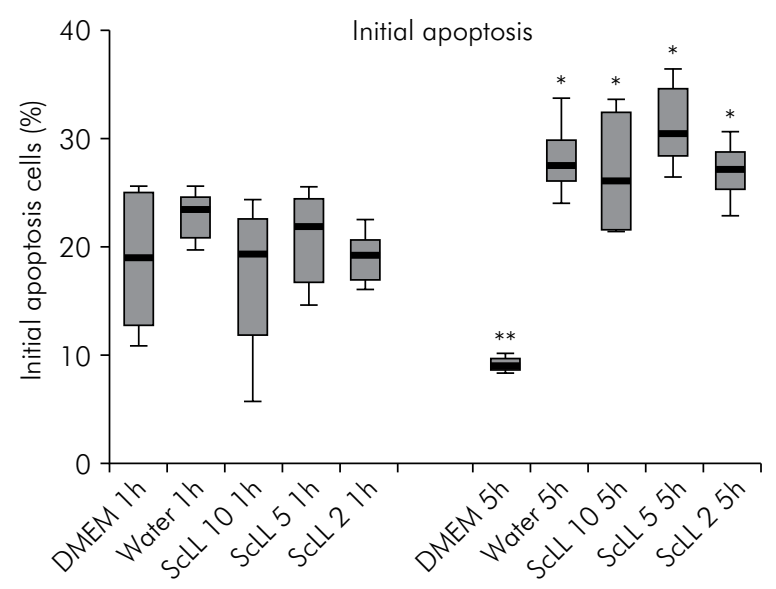

D

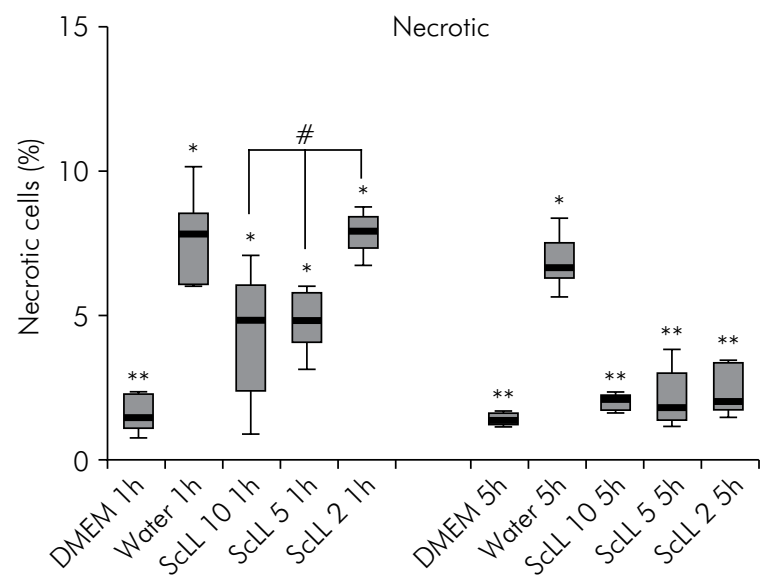

Figure 2. Results of flow cytometry analyses of the percentage of viable cells at 1 and $5 \mathrm{~h}(\mathrm{~A})$; initial apoptosis cells at 1 and $5 \mathrm{~h}(\mathrm{~B})$; advanced apoptosis cells at 1 and $5 \mathrm{~h}(\mathrm{C})$; necrotic cells at 1 and $5 \mathrm{~h}(\mathrm{D})$. Statistical significance was determined using one-way ANOVA and Dunnet's test. \# $p<0.05$ compared between the experimental groups. ${ }^{*} p<0.05$ compared with positive control (DMEM). ${ }^{* *} p<0.05$ compared with negative control (tap water).

preliminary study assessing drugs and medicines is widely supported in the literature. ${ }^{17}$ These types of cells have a known behavior and less heterogeneity than cells from primary culture. ${ }^{19}$ This allows easy reproducibility with no ethical conflicts involving research using human material. It is known that the phenotypic and genotypic characteristics of gingival fibroblasts differ from those of periodontal fibroblasts. ${ }^{18}$ However, immortalized PDL cells are not available for this protocol; therefore, this preliminary study opted for the HGF lineage.

Avulsed teeth become susceptible to contamination because the teeth usually fall to the ground, resulting in possible infection and inflammatory response. ${ }^{1,3,10}$
Therefore, it was decided that the study cells would be stimulated with LPS in order to mimic situations that occur clinically. Studies have shown that gingival fibroblasts express Toll-like receptors and CD14 in response to LPS. ${ }^{19,20}$ LPS induces stress, which mediates the activation of mitogen-activated protein kinase (MAPK) signaling pathways, following the inflammatory response. ${ }^{21}$ The MAPKs are serine threonine kinases that mediate the intracellular signaling associated with cellular activities, such as apoptosis, proliferation, differentiation and survival. ${ }^{22}$ The use of fibroblasts activated with LPS in drug tests is supported in the literature. ${ }^{23}$

In the current study, the activated fibroblasts were evaluated regarding viability, initial/advanced 


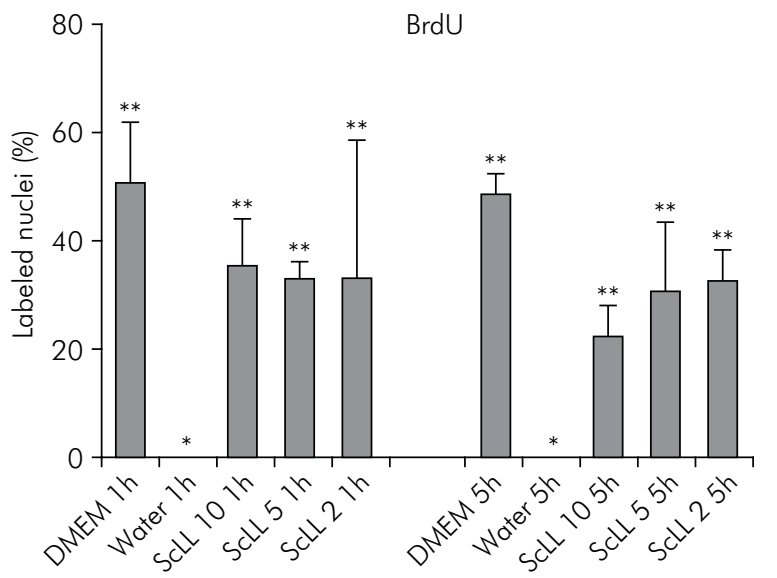

Figure 3. Comparison of cell proliferation percentage at 1 and $5 \mathrm{~h}$. Statistical significance was determined using a one-way ANOVA and Dunnet's test. ${ }^{*} p<0.05$ compared with positive control (DMEM). ${ }^{* *} \mathrm{p}<0.05$ compared with negative control (tap water).

apoptosis and necrosis using flow cytometry with annexin and PI labeling. PI is a nucleic acidbinding dye, impermeable to live and apoptotic cells; the high affinity of annexin for the phosphatidylserine exposed on the outer cell membrane is acquired early in the apoptosis process. Programmed cell death differs from necrosis in terms of the changes in biochemical and morphological characteristics, such as loss of membrane asymmetry and compaction/fragmentation of the nuclear chromatin. It is possible to distinguish the cells just beginning the programmed death process from those that are already at an advanced stage. This is important for analyses conducted for longer periods, such as the $5 \mathrm{~h}$ group. Compared with other methods of viability assays, cytometry is more accurate and yields more reliable results. ${ }^{24}$ The highest viability levels were found for the positive control group, compared with the groups treated with the lectin ScLL and stimulated with LPS, since the presence of this endotoxin can trigger the cell death mechanism. ${ }^{25}$ However, the fact that the viability of the ScLL groups differs from that of the negative control group shows that none of the ScLL concentrations used are cytotoxic. On the other hand, the substances tested were probably not able to block the molecular events that trigger the apoptotic process. This could be reflected by the higher percentage of advanced apoptotic cells in the ScLL treated groups than in the positive control group. Although analyses

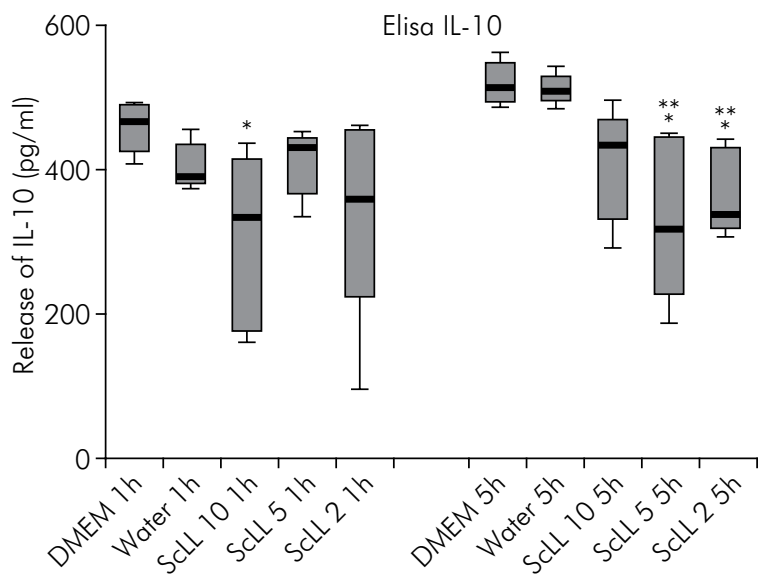

Figure 4. Release of IL-10 in HGFs examined by Elisa at 1 and $5 \mathrm{~h}$. Statistical significance was determined using one-way ANOVA and Dunnet's test. \#p $<0.05$ compared between the experimental groups. ${ }^{*} p<0.05$ compared with positive control (DMEM). ${ }^{* *} p<0.05$ compared with negative control (tap water).

at the molecular and cellular levels were not conducted, lectin could act on any point of the apoptotic pathway, since the treated groups presented better results than the negative control group.

Considering that the presence of an immune inflammatory agent such as LPS could change the proliferative capacity of cells, ${ }^{21}$ and that treatment with ScLL could have a positive effect, analyses of cell proliferation were performed. The BrdU assay was chosen because it is an effective method of detecting changes in proliferation, which can be incorporated into the DNA of replicating cells. ${ }^{25}$ The null hypothesis, regarding cells stimulated with LPS and treated with ScLL, was rejected since proliferation was higher for the experimental groups, compared with the negative control.

Another important factor, involved in establishing inflammatory reactions that can initiate resorption, is the release of cytokines by cells. ${ }^{10} \mathrm{IL}-10$ is a key regulator of immune responses, which inhibits the expression of pro-inflammatory cytokines, chemokines and receptors, ${ }^{23}$ and which affects T-cell activation by suppressing CD28 and CD2. ${ }^{26}$ Its function is to protect the inflammatory responses of microbial infection, and to limit the production of TLR agonists such as LPS, which are induced cytokines and chemokines. ${ }^{27}$ Furthermore, IL-10 promotes cell survival, proliferation and differentiation. ${ }^{27}$ Thus, higher levels of IL-10 were expected in the treated groups than in the control groups, since the levels of 
this cytokine provide protection against hard-tissue resorption in the periodontal microenvironment of replanted teeth. ${ }^{10}$ The second null hypothesis, namely that the levels of IL-10 are the same for both treated and control groups, was rejected since the detected IL-10 values of ScLL 5 and $2 \mu \mathrm{g} / \mathrm{ml}$ were different for both positive and negative controls at $5 \mathrm{~h}$.

Despite the limitations of the present study, which did not include a group treated with LPS, the results presented here suggest that lectin ScLL may be promising in dentistry, specifically in the concentrations of 5 and $2 \mu \mathrm{g} / \mathrm{ml}$, which do not indicate a dose-dependent effect on cell viability/proliferation and release of IL-10. However, the immunoregulatory functions of ScLL may depend on cell type, which may elicit the release of different cytokines, such as IL-12, IL-1 $\beta$, TNF- $\alpha$ and IL-10. To this effect, more research using different models of avulsion are required so

\section{References}

1. Trope M. Avulsion of permanent teeth: theory to practice. Dent Traumatol. 2011;27(4):281-94. doi:10.1111/j.1600-9657.2011.01003.x

2. Tuna EB, Yaman D, Yamamato S. What is the best root surface treatment for avulsed teeth? Open Dent J. 2014;8(8):175-9. doi:10.2174/1874210601408010175

3. Schjøtt M, Andreasen JO. Emdogain does not prevent progressive root resorption after replantation of avulsed teeth: a clinical study. Dent Traumatol. 2005;21(1):46-50. doi:10.1111/j.1600-9657.2004.00295.x

4. Moura CCG, Soares PBF, Reis MV, Fernandes Neto AJ, Soares CJ. Soy milk as a storage medium to preserve human fibroblast cell viability: an in vitro study. Braz Dent J. 2012;23(5):559-63. doi:10.1590/S0103-64402012000500015

5. Gunraj MN. Dental root resorption. Oral Surg Oral Med Oral Pathol Oral Radiol Endod. 1999;88(6):647-53. doi:10.1016/S1079-2104(99)70002-8

6. Hidalgo MM, Itano EN, Consolaro A. Humoral immune response of patients with dental trauma and consequent replacement resorption. Dent Traumatol. 2005;21(4):218-21. doi:10.1111/j.1600-9657.2005.00296.x

7. Lustosa-Pereira AL, Garcia RB, Moraes IG, Bernardineli $\mathrm{N}$, Bramante CM, Bortoluzzi EA. Evaluation of the topical effect of alendronate on the root surface of extracted and replanted teeth: microscopic analysis on rat's teeth. Dent Traumatol. 2006;22(1):30-5. doi:10.1111/j.1600-9657.2006.00417.x that the potential of ScLL as an immunomodulator of fibroblasts may be studied more accurately, particularly, the association of storage media with the nutritional capacity of this lectin for use as an additional product for avulsed teeth.

\section{Conclusion}

Based on the results of the present study, it can be concluded that the ScLL concentrations tested were not cytotoxic, and had no effect on proliferation and release of IL-10 parameters.

\section{Acknowledgments}

The authors would like to thank the CPBio Dental Research Center for Biomechanics, Biomaterials and Cell Biology of the Federal University of Uberlândia. This research was financial supported bu FAPEMIG, CNPq and CAPES.

8. Mori GG, Moraes IG, Garcia RB, Borro LCB, Purificação BR. Microscopic investigation of the use of gallium nitrate for root surface treatment in rat teeth submitted to delayed replantation. Braz Dent J. 2007;18(3):198-201. doi:10.1590/S0103-64402007000300004

9. Poi WR, Carvalho RM, Panzarini SR, Sonoda CK, Manfrin $\mathrm{TM}$, Rodrigues TS. Influence of enamel matrix derivative (Emdogain) and sodium fluoride on the healing process in delayed tooth replantation: histologic and histometric analysis in rats. Dent Traumatol. 2007;23(1):35-41. doi:10.1111/j.1600-9657.2006.00481.x

10. Roskamp L, Westphalen VD, Carneiro E, Fariniuk LF, Silva Neto UX, Westphalen FH. Relationship between extra-alveolar time and atopy in the prognosis of the replantation of avulsed teeth. J Trauma. 2010;69(6):E79-81. doi:10.1097/TA.0b013e3181ec112b

11. Tyrovola JB, Spyropoulos MN, Makou M, Perrea D. Root resorption and the OPG/RANKL/RANK system: a mini review. J Oral Sci. 2008 Dec;50(4):367-76. doi:10.2334/josnusd.50.367

12. Goldring SR, Goldring MB. Eating bone or adding it: the Wnt pathway decides. Nat Med. 2007;13(2):133-4. doi:10.1038/nm0207-133

13. Rogerio AP, Cardoso CR, Fontanari C, Souza MA, Afonso-Cardoso SR, Silva EVG, et al. Anti-asthmatic potential of a D-galactose-binding lectin from Synadenium carinatum latex. Glycobiology. 2007;17(8):795-804. doi:10.1093/glycob/cwm053 
14. Sharon N, Lis H. Carbohydrates in cell recognition. Sci Am. 1993;268(1):82-9. doi:10.1038/scientificamerican0193-82

15. Afonso-Cardoso SR, Silva CV, Ferreira MS, Souza MA. Effect of the Synadenium carinatum latex lectin (ScLL) on Leishmania (Leishmania) amazonensis infection in murine macrophages. Exp Parasitol. 2011;128(1):61-7. doi:10.1016/j.exppara.2011.02.006

16. Cardoso MR, Mota CM, Ribeiro DP, Noleto PG, Andrade WB, Souza MA et al. Adjuvant and immunostimulatory effects of a D-galactose-binding lectin from Synadenium carinatum latex (ScLL) in the mouse model of vaccination against neosporosis. Vet Res (Faisalabad). 2012;43(1):76. doi:10.1186/1297-9716-43-76

17. Niu N, Wang L. In vitro human cell line models to predict clinical response to anticancer drugs. Pharmacogenomics. 2015;16(3):273-85. doi:10.2217/pgs.14.170

18. Scheres N, Laine ML, de Vries TJ, Everts V, van Winkelhoff AJ. Gingival and periodontal ligament fibroblasts differ in their inflammatory response to viable Porphyromonas gingivalis. J Periodontal Res. 2010;45(2):262-70. doi:10.1111/j.1600-0765.2009.01229.x

19. Wang PL, Oido-Mori M, Fujii T, Kowashi Y, Kikuchi $\mathrm{M}$, Suetsugu $\mathrm{Y}$ et al. Heterogeneous expression of Toll-like receptor 4 and downregulation of Toll-like receptor 4 expression on human gingival fibroblasts by Porphyromonas gingivalis lipopolysaccharide. Biochem Biophys Res Commun. 2001;288(4):863-7. doi:10.1006/bbrc. 2001.5842

20. Wang PL, Ohura K. Porphyromonas gingivalis lipopolysaccharide signaling in gingival fibroblasts-CD14 and Toll-like receptors. Crit Rev Oral Biol Med. 2002;13(2):132-42. doi:10.1177/154411130201300204

21. Seo T, Cha S, Kim TI, Lee JS, Woo KM. Porphyromonas gingivalis-derived lipopolysaccharide-mediated activation of MAPK signaling regulates inflammatory response and differentiation in human periodontal ligament fibroblasts. J Microbiol. 2012;50(2):311-9. doi:10.1007/s12275-012-2146-x

22. Lim W, Choi H, Kim J, Kim S, Jeon S, Zheng H et al. Anti-inflammatory effect of $635 \mathrm{~nm}$ irradiations on in vitro direct/indirect irradiation model. J Oral Pathol Med. 2015;44(2):94-102. doi:10.1111/jop.12204

23. Jung IH, Lee DE, Yun JH, Cho AR, Kim CS, You YJ, et al. Anti-inflammatory effect of (-)-epigallocatechin-3-gallate on Porphyromonas gingivalis lipopolysaccharide-stimulated fibroblasts and stem cells derived from human periodontal ligament. J Periodontal Implant Sci. 2012;42(6):185-95. doi:10.5051/jpis.2012.42.6.185

24. Nebe-von-Caron G, Stephens PJ, Hewitt CJ, Powell JR, Badley RA. Analysis of bacterial function by multi-colour fluorescence flow cytometry and single cell sorting. J Microbiol Methods. 2000;42(1):97-114. doi:10.1016/S0167-7012(00)00181-0

25. Urnowey S, Ansai T, Bitko V, Nakayama K, Takehara T, Barik S. Temporal activation of anti- and pro-apoptotic factors in human gingival fibroblasts infected with the periodontal pathogen, Porphyromonas gingivalis: potential role of bacterial proteases in host signalling. BMC Microbiol. 2006;6(1):26. doi:10.1186/1471-2180-6-26

26. Waal Malefyt R, Abrams J, Bennett B, Figdor CG, Vries JE. Interleukin 10 (IL-10) inhibits cytokine synthesis by human monocytes: an autoregulatory role of IL-10 produced by monocytes. J Exp Med. 1991;174(5):1209-20. doi:10.1084/jem.174.5.1209

27. Akdis CA, Akdis M. Mechanisms and treatment of allergic disease in the big picture of regulatory T cells. J Allergy Clin Immunol. 2009;123(4):735-46. doi:10.1016/j.jaci.2009.02.030 